\title{
AIR BIOMONITORING USING LICHENS
}

\section{$\underline{\text { Smaranda Masu }}{ }^{1}$}

1 INCD-ECOIND, Branch of Timisoara, 300004, 1 Regina Maria Square, Timisoara, emailsmarandamasu@yahoo.com, Romania.

\begin{abstract}
The paper present the studies of sensitivity of exposed lichens to different levels of heavy metals pollution. It investigated the behavior of the Parmelia sp. (acacia wood support) transplanted from unpolluted areas into laboratory conditions. The pollution has been achieved by the various synthetic solutions of $\mathrm{Cd}$ or/and $\mathrm{Zn}$. Process are complex and many factor affect heavy metal bioaccumulation. Time of exposure to pollution, quantity and metal species, their ratio, tissues metal bioaccumulation and their relationship with the health of lichens are discussed. In this context resulted that the presence of two metal i.e. Zn and Cd in synthetic solution has determinate reduced 2-4 times the metal amount bioaccumulation of tissues lichens compared to the accumulated amount in the presence of single metal in polluting solution. High concentrations of metals in the environment can dramatically affect lichens life. The lichens studies of bioavailability of metal could further enhance utility as air quality biomonitoring tool.
\end{abstract}

Keywords: cadmium, zinc, pollution, lichens, biomonitoring.

\section{Introduction}

Lichens have been used to assess air quality in several worldwide studies.Reviews of the literature are many [1-6]. Several factors contribute to lichens sensitivity. Water and gas are exchanged over the entire lichen thallus.Because they lack roots, lichens do not have access to soil nutrient and must depend on of water rainfall characteristics and atmospheric quality and other dilute sources of nutrients. Thus, their tissue content largely reflects atmospheric sources of nutrients and other environmental compounds. Lichens also lack the protective tissues or cell types necessary to maintain a constant internal water content. Nutrients tend to be more easily remobilized than metal contaminants [7-8]. A dynamic equilibrium thus exists between atmospheric nutrient/pollutant accumulation and loss, which makes lichen analysis a sensitive tool for the detection of modifications in air quality. $\mathrm{Zn}$ is produced in automobile exhaust or/and is emitted from zinc smelters. Zinc. is found in fairly large concentrations (200-600 ppm) in lichens near air of zinc smelters. Cd is a component of wood and coals fly-ash and presumably travels long distances in the atmosphere; it's presence can be correlated with localities and industrial centers [910]. The experimental study followed the lichens' ability to incorporate metals under the exposure to polluted environments such as imposed under laboratory conditions with $\mathrm{Zn}$ and $\mathrm{Cd}$ acidic solutions. 


\section{Materials and Methods}

The lichens studied were of the Parmelia sp.species. Lichens were taken along with the acacia support from a Natural Reservation in the southwest of Romania. They were placed in laboratory dishes esposed to natural light and room temperature. They were regularly sprayed with nutritive solutions and synthetic solutions polluted with metals. The nutrient solution contained $10.0 \mathrm{mg} \cdot \mathrm{L}^{-1}$ sodium acetate, $0.27 \mathrm{mg} \cdot \mathrm{L}^{-1}$ urea and $1.30 \mathrm{mg} \cdot \mathrm{L}^{-1}$ dipotassium phosphate The polluted solutions contained salts of $\mathrm{Cd}$ and / or Zn. The concentration of metals in the pollutant solution was similar to the environment affected by the anthropogenic pollution. The polluting synthetic solutions had a pH of 3.5 in order to simulate acid rain. The duration of the experiment was 16 weeks. The structure of the experiment is shown in Table 1.

Table 1 Polluting solution characteristics and the experiment structure

\begin{tabular}{|c|c|c|c|}
\hline Polluting solution characteristics & \multicolumn{3}{|c|}{ Experimental variants } \\
\cline { 2 - 4 } & $\mathrm{P} 1$ & $\mathrm{P} 2$ & $\mathrm{P} 3$ \\
\hline Type & $\mathrm{s} 1$ & $\mathrm{~s} 2$ & $\mathrm{~s} 3$ \\
\hline $\mathrm{pH}$ & 3.5 & 3.5 & 3.5 \\
\hline Metal content & & - & 1 \\
$--\mathrm{Cd}\left[\mathrm{mg} \cdot \mathrm{L}^{-1}\right]$ & - & 10 & 10 \\
\hline
\end{tabular}

The lichen samples were sprayed periodically with a nutrient solution and with metal polluting solutions with different concentrations and compositions (see Table 1). The experimental study was conducted over a period of 16 weeks. The metal content in the lichen samples was analyzed before and after the experiment. In order to determine the metal content, the lichens were separated from the wooden cuticle. The lichens were washed twice in bidistilled water. They were then shaken gently to remove the excess water. The lichens were dried for 3 days at room temperature. An amount of 1$2 \mathrm{~g}$ lichens was weighed and kept at a constant temperature of $60^{\circ} \mathrm{C}$ until they reached constant weight (3-4 hours). This tissue was then milled by hand for a uniform blending. An amount of lichens powder of $0,25-0,50 \mathrm{~g}$ was weighed, then calcined at $550{ }^{\circ} \mathrm{C}$ for $90 \mathrm{~min}$. The resulting ash was dissolved using a mixture of $5: 1$ hydrochloric acid (37\% Merck, Germany) and $\mathrm{HNO}_{3}(69 \%$ Merck Germany) on the sand bath. The solid residue was retrieved with $3 \mathrm{ml} \mathrm{HCl} \mathrm{1:1} \mathrm{and} \mathrm{filtered} \mathrm{through} \mathrm{paper} \mathrm{(Sartorius} \mathrm{filter}$ papers FT 2-206). The crucible was washed 3 times with $3 \mathrm{ml}$ of $\mathrm{HCl} 1$ : 1. The washing solutions were also filtered. The solution for the retrieval of the residue and the washing solutions were transferred into volumetric flasks which were subsequently brought to level with a $\mathrm{HCl} 1$ : 1 solution. Metal analysis was performed with an AAS spectrometer of the Avanta type. The certified reference material, BCR 482 lichen (IRMM) Geel Belgium was used to validate the analytical determinations.[11]. Determining the amount of metals in lichens' acacia support was determined similarly.

\section{Results and Discussions}

Table. 2 presents the initially amount of metals in the studied lichens. From Table 2 it is observed that the lichens have not initially presented detectable $\mathrm{Cd}$ and Cr. Nickel may appear in some of the tissue samples, such as in $\mathrm{P} 3$ sample. The iniatially amount of iron present in the lichen samples was in the range of $1754.7-2636.5 \mathrm{mg} \cdot \mathrm{kg}^{-1} \mathrm{D} . \mathrm{M}$. 
The amount of lead was in the range of $24.3-40.9 \mathrm{mg} \cdot \mathrm{kg}^{-1}$ D.M.. The quantity of zinc found in the lichens was between $17.5-25.8 \mathrm{mg} \cdot \mathrm{kg}^{-1} \mathrm{D} . \mathrm{M}$. and the copper found was between $8.14-8.96 \mathrm{mg} \cdot \mathrm{kg}^{-1}$ D.M. From Table 2 it is observed that the quantities of metals determined before the start of the experiment are correlated with the values reported by the Certified reference material BCR 482 lichen(IRMM) Geel Belgium[11].

Table 2. The initially amount of metals in the lichens, Parmelia sp.

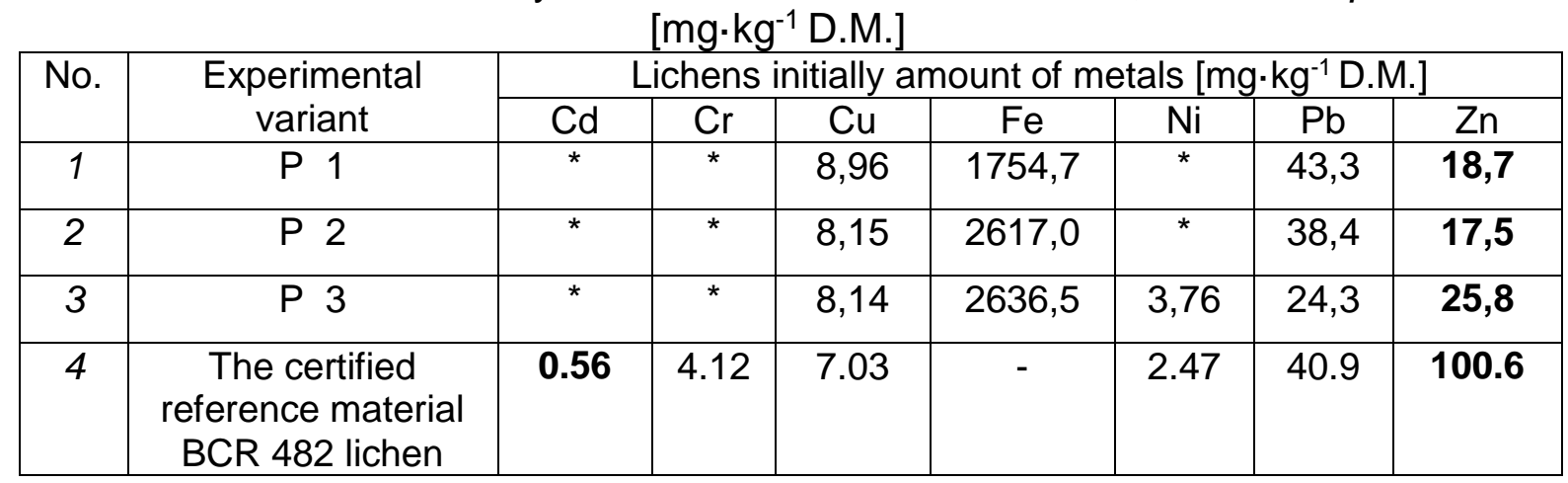

*Below detection limit

In Table. 3 we are shown the initially amounts of metals in the acacia support of the studied lichens, Parmelia sp. Table 3 shows that the acacia support does not contain $\mathrm{Cd}$ and $\mathrm{Ni}$ ions. The acacia support contains $\mathrm{Cr}$ but it was not adsorbed by the analized lichens. In the $\mathrm{Cu}, \mathrm{Fe}, \mathrm{Pb}$ and $\mathrm{Zn}$ amounts from the acacia are correlated with the initial quantities of metals present in the lichens' tissue.

Table 3 The initially amounts of metals in the acacia support of the corticol lichens Parmelia sp used in the experiment's variants [mg $\cdot \mathrm{kg}^{-1}$ D.M.]

\begin{tabular}{|c|c|c|c|c|c|c|c|c|}
\hline No. & Experimental & \multicolumn{6}{|c|}{ Acacia wood support initially amount of metals [mg $\cdot \mathrm{kg}^{-1}$ D.M.] } \\
\cline { 3 - 9 } & variant & $\mathrm{Cd}$ & $\mathrm{Cr}$ & $\mathrm{Cu}$ & $\mathrm{Fe}$ & $\mathrm{Ni}$ & $\mathrm{Pb}$ & $\mathrm{Zn}$ \\
\hline 1 & Acacia wood & $*$ & $5,9-$ & $5,1-$ & $863,5-$ & $*$ & $22,9-$ & $9,8-$ \\
& support & & 9,5 & 9,3 & 1775 & & 55,7 & 18,6 \\
\hline
\end{tabular}

*Below detection limit

In table 4 are shown the quantities of $\mathrm{Cd}$ and $\mathrm{Zn}$ determined from the tissue of the species of lichens Parmelia $s p$ (acacia) after the exposure to a pollutant in the laboratory conditions for 16 weeks. The pollutant conditions was presented as a single pollutant, with either $\mathrm{Cd}$ or $\mathrm{Zn}$, or as a doubly pollutant $\mathrm{Cd}$ and $\mathrm{Zn}$. From Table 2 and 4 we can draw the conclusion that during the 16 weeks of exposure to pollution laboratory conditions, the amounts of $\mathrm{Cd}$ and $\mathrm{Zn}$ bio-accumulated are influenced by the concentration and composition of the polluted environment:

- Lichens take from the Natural Reservation were not Cd bioaccumulations tissue. This metal was bio-accumulated in the tissue of the lichens exposed to pollution with the Cd salts solution.

- When using a single pollution solution with $\mathrm{Cd}$, the amount of metal bioaccumulated in the lichens' tissue was higher by $52 \%$ than the amount of metal $(\mathrm{Cd})$ gained when using a solution with $\mathrm{Cd}$ and $\mathrm{Zn}$ salts. 
Table 4 The quantity of metals in the corticol lichens Parmelia sp used in the experiment's variants after the exposure in the laboratory conditions to pollution with $\mathrm{Cd}$ and/or Zn. $\mathrm{mg} \cdot \mathrm{kg}^{-1} \mathrm{D} . \mathrm{M}$.

\begin{tabular}{|c|c|c|c|c|c|c|c|}
\hline No. & \multirow{2}{*}{$\begin{array}{c}\text { Experiment's } \\
\text { variants }\end{array}$} & \multicolumn{5}{|c|}{ The quantity of metals after the exposure in the laboratory } \\
\cline { 3 - 8 } & & $\mathrm{Cd}$ & $\mathrm{Cr}$ & $\mathrm{Cu}$ & $\mathrm{Fe}$ & $\mathrm{Pb}$ & $\mathrm{Zn}$ \\
\hline 1 & $\mathrm{P} 1$ & 2,25 & ${ }^{*}$ & 18,72 & 1753 & 11,9 & 19,3 \\
\hline 2 & $\mathrm{P} 2$ & $\star$ & $*$ & 16,8 & 3132 & 14,3 & 37,5 \\
\hline 3 & $\mathrm{P} 3$ & 1,08 & $*$ & 11.1 & 2636.5 & 24.3 & 30.8 \\
\hline
\end{tabular}

*Below detection limit

The $\mathrm{Zn}$ amount found in the lichens was increased:

- Under the exposure to a single pollutant, solution with Zn salt, from $17.5 \mathrm{mg} \cdot \mathrm{kg}$ ${ }^{1}$ D.M. to $37.5 \mathrm{mg} \cdot \mathrm{kg}^{-1} \mathrm{D} . \mathrm{M}$.

- Under the exposure to two pollutants, solution with $\mathrm{Cd}$ and $\mathrm{Zn}$ salts, the $\mathrm{Zn}$ amount has increased from $25.8 \mathrm{mg} \cdot \mathrm{kg}^{-1}$ D.M to $30.8 \mathrm{mg} \cdot \mathrm{kg}^{-1}$ D.M.

The degree of bioaccumulation of zinc in the monitored period of 16 weeks of exposure to different polluted conditions with solutions of $\mathrm{Zn}$ (one metal) and with solutions of $\mathrm{Cd}$ and $\mathrm{Zn}$ ( two metals) was higher by:

- $53 \%$ vs. the initially amount when exposed to a single pollutant, $\mathrm{Zn}$

- $16.2 \%$ vs. the initially amount when exposed to two pollutants ( $\mathrm{Cd}$ and $\mathrm{Zn}$ )

In Table 4 it is comparatively shown the appearance of the lichen species Parmelia sp (with the acacia support) after the exposure to laboratory polluted conditions with a single pollutant, $\mathrm{Cd}$ or $\mathrm{Zn}$, or with two pollutants, $\mathrm{Cd}$ and $\mathrm{Zn}$.

Table 4. The appearance of the lichens ( Parmelia sp.) from the experimental samples after 16 weeks

\begin{tabular}{|c|c|c|}
\hline \multirow{2}{*}{ Samples } & \multicolumn{2}{|c|}{ The appearance of the lichens ( Parmelia sp.) } \\
\cline { 2 - 3 } & Initial & After 16 weeks. \\
\hline P1 & greenish with a white border & greenish \\
\hline P 2 & greenish with a white border & greenish \\
\hline P 3 & greenish with a white border & greenish with 1-2 $\mathbf{~ m m ~ b r o w n ~ s p o t s ~}$ \\
\hline
\end{tabular}

Table 4 shows that at an exposure time of 16 of weeks of pollution with $\mathrm{Cd}$ solutions (with a concentration of $1 \mathrm{mg} \cdot \mathrm{L}^{-1}$ of $\mathrm{Cd}$ ) or pollution with $\mathrm{Zn}$ solutions (with a concentration of $10 \mathrm{mg} \cdot \mathrm{L}^{-1}$ of $\mathbf{Z n}$ ), made the color of the lichens suffer mild changes. It changed from greenish with white borders to greenish. The exposure to polluted conditions with $\mathrm{Cd}$ and $\mathrm{Zn}$ solution resulted in an increase of the total concentration of metals in the polluted environment to which the studied organisms were subjected. As a result the lichens' surface was altered. Small brown spots of 1-2 mm appeared on the lichens.

\section{Conclusions}

The lichens of the Parmelia $s p$. were exposed to artificially polluting conditions with aqueous solutions of $\mathrm{Cd}$ and/or $\mathrm{Zn}$ salts. Over a period 16 weeks the bio-accumulated different amounts of metals. From the polluted solution with $1 \mathrm{mgCd} \cdot \mathrm{L}^{-1}$, the lichens bioaccumulated in the exposure period the amount of $2.25 \mathrm{mgCd} \cdot \mathrm{kg}^{-1}$ D.M. From the polluted solution with $10 \mathrm{mg} \cdot \mathrm{L}^{-1}$ of $\mathrm{Zn}$ salt, the bioaccumulation of metal was of 20 
$\mathrm{mgZn} \cdot \mathrm{kg}^{-1}$. The amount of $\mathrm{Cd}$ accumulated by the lichens under an exposure to an environment polluted with 2 metals was 52\% lower than the amount of Cd bioaccumulated under a single system pollution. The amount of $\mathrm{Zn}$ accumulated in the lichens' tissue was $36.8 \%$ higher under an exposure to a single pollutant $v s$. the quantity bio-accumulated under exposure to two pollutants ( $\mathrm{Cd}$ and $\mathrm{Zn}$ ). In this context it results that the presence of two metals, i.e. $\mathrm{Zn}$ and $\mathrm{Cd}$ in synthetic solutions has determinately reduced up to 2-4 times the $\mathrm{Cd}$ or $\mathrm{Zn}$ bio-accumulated amount by the lichens' tissues $v s$. the case when a single metal is present in the pollutant solution. The appearance of the lichen samples exposed to pollution may remain unchanged or it can change depending on the composition and concentration of the environmental pollutants. The lichens studies of bioavailability of metals could further enhance their utility as an air quality bio-monitoring tool.

\section{Acknowledgements}

The research given the National Authority for Scientific Research and Innovation which provide financial support for Nucleu Program PN16 253116.

\section{References}

[1] Hale M. E., (1983), The biology of lichens, Ed. E Arnold, London, UK.

[2] Richardson D.H.S., (1992), Pollution monitoring whit lichens, Naturalist's, Handboocks, 19, Slough: Richmond Publishing, UK..

[3] Conti M.E., Cecchetti G., (2001), Biological monitoring lichens as bioindicators of air pollution assessment-a review, Environmental Pollution, 14, 471-492.

[4] Carreras H. A., Wannaz E. D., Perez C. A., Pignata M. L., (2005), The role of urban air pollutants on the performance of heavy metals accumulation in Usnea amblyoclada, Environmental Research, 97 (1), 50-57.

[5] Rusu A.M., G.C.Jones., Chimodes P.D.J., Purvis O.W., (2008), Biomonitoring using the lichen Hypogymnia physodes and bark samples near Zlatna Romania immediately following closure of a copper ore-processing plant, Environmental Pollution,143(1), 81-88.

[6] Sujetoviene G.,(2015), Indicators of Atmospheric Quality in Recent Advances in Lichenoligy, Modern Methods and Approaches in Biomonitoring and Bioprospection, vol. 1, Eds. Ureti D.L., Kivakar P.K., Shukla V., Bajpai R.,Springer New Delhi, India, 87-118.

[7] Kularatne K.I.A., Freitas C.R., (2013), Ephiphatic lichen as biomonitors of airborne heavy metal pollution, Environmental and experimental Botany, 88, 24-32.

[8] Barcelo D., (2015), Determination of elemental baseline using peltigeralean lichens from Northeastern Canada (Québec): Initial data collection for long term monitoring of the impact of global climate change on boreal and subarctic area in Canada, Science of Total Environment, 533, 1-7.

[9] Kral R., Kryzova L., Lisk J., (1989), Bachground concentrations of lead and cadmium in the lichen Hypogymnia sp at different altitudes, Science Total Environmental, 84. 201-209.

[10] Hale. M.E., (1981), Lichens as bioindicators and Monitors of Air Pollution in the Flat Tops Wilderness Area. Colorado. Final Report: USFS Contract No. ON RFP R2-81-SP35.

[11] EC-IRMM, (Revised: 2007), The certified reference material BCR 482 lichen, European Comission- Joint Research Centre, Institute for Reference Materials and Measurements, Brussels, Belgium. 